\title{
Spondylo-ocular syndrome
}

INSERM

\section{Source}

INSERM. (1999). Orphanet: an online rare disease and orphan drug data base. Spondyloocular syndrome. ORPHA:85194

Spondylo-ocular syndrome is a very rare association of spinal and ocular manifestations that is characterized by dense cataracts, and retinal detachment along with generalized osteoporosis and platyspondyly. Mild craniofacial dysphormism has been reported including short neck, large head and prominent eyebrows. 